\title{
Distribution of the species of Lucifer Thompson, 1829 in the subtropical South Atlantic between parallels $20^{\circ}$ and $30^{\circ} \mathrm{s}$
}

\author{
André Marafon-Almeida ${ }^{1 *}$, Juliano Bicalho Pereira ${ }^{2}$, Luiz Fernando Loureiro Fernandes ${ }^{2}$ \\ ${ }^{1}$ BIOENV Meio Ambiente, Aracruz, ES - Brasil \\ (Av. Fernando Ferrari, 514 - Goiabeiras | Vitória, ES -Brasil | CEP 29075-910) \\ ${ }^{2}$ Universidade Federal do Espírito Santo (UFES). \\ (Av. Fernando Ferrari, 514 - Goiabeiras | Vitória, ES -Brasil | CEP 29075-910) \\ *Corresponding author: andre@bioenv.com.br
}

\section{Abstract}

The distribution of the species of Lucifer Thompson, 1829 (Decapoda: Luciferidae) in the South Atlantic Subtropical Gyre was assessed by the Brazil Transatlantic Commission in November and December 2009. The samples were collected at 83 stations on two profiles between Brazil and Africa $\left(20^{\circ}\right.$ and $\left.30^{\circ} \mathrm{S}\right)$. Oblique hauls were performed with a WP-2 net up to 150 meters deep. A distinct sexual relationship was noted between the two species found and L. faxoni presented a significantly higher number of females relative to males 1:0.5 $\left(\chi^{2}=21.77, p=0.0001\right)$. The $L$. typus sex ratio had significantly more males than females $1.86: 1\left(\chi^{2}=50.84, p=0.0001\right)$. The distribution of L. typus occurred in both the western and the eastern portions of the MidOceanic Ridge. This distribution was significantly related to salinity $\left(\mathrm{R}^{2}=0: 13 ; \mathrm{F}=3.79, p=0.009\right)$, which was higher in the western portion of the study area. In addition, the recordings of the two species were extended to the Atlantic Subtropical Gyre. Overall, Luciferidae shrimp were more common and abundant at the stations west of the Mid-Oceanic Ridge and L. typus was the most frequent and abundant species.

Descriptors: Density, Larva, Zooplankton, Decapods.

\section{RESUMo}

A distribuição das espécies de Lucifer Thompson, 1829 (Decapoda: Luciferidae) no Giro Subtropical do Atlântico Sul foi avaliada pela Comissão Transatlântico Brasil I, entre novembro e dezembro de 2009. As amostras foram coletadas em 83 estações, em dois perfis entre o Brasil e África $\left(20^{\circ}\right.$ e $30^{\circ}$ Sul $)$. Foram realizados arrastos oblíquos com rede cilindrocônica, até 150 metros de profundidade. Observouse uma relação sexual distinta entre as duas espécies encontradas. L. faxoni apresentou número de fêmeas significativamente maior em relação aos machos: 1:0.5 ( $\left.\chi^{2}=21,77, p=0,0001\right)$, enquanto L. typus, teve proporção sexual de machos significativamente maior que de fềmeas: 1.86:1 $\left(\chi^{2}=50,84, p=0,0001\right)$. A distribuição de L. typus variou entre as porções oeste e leste da cordilheira Mesoceânica. Essa distribuição esteve relacionada significativamente com a salinidade $\left(\mathrm{R}^{2}=0.13 ; \mathrm{F}(3.79) ; p=0,009\right)$, mais elevada à oeste da área de estudo. No presente trabalho as duas espécies tiveram seus registros ampliados para o Giro Subtropical do Atlântico. De forma geral, os camarões luciferídeos foram mais frequentes e abundantes nas estações de coleta a oeste da Cordilheira Mesoceância, com L. typus sendo mais representativo tanto em abundância quanto em ocorrência.

Descritores: Densidade, Larva, Zooplâncton, Decápodes. 


\section{INTRODUCTION}

The family Luciferidae De Haan, 1849 [in De Haan, 1833-1850] is composed of small $(1-2 \mathrm{~cm})$ holoplanktonic shrimp that are of great importance to the recycling of nutrients and the distribution of organic material (VEGAPÉREZ, 1996; FUGIMURA et al., 2005). Of the seven species recognized in the genus Lucifer Thompson (1829), only L. faxoni Borradaile (1915) and L. typus H. MilneEdwards (1837) occur in the west Atlantic (D'INCAO, 1997; COSTA et al., 2000). The remaining species are described in the Indian and Pacific oceans (FUGIMURA et al., 2005). BOWMAN and MCCAIN (1967) analyzed the distribution of these species of Luciferidae shrimp in the North Atlantic and concluded that L. typus is a species predominantly found in the open ocean, whereas $L$. faxoni is a species that prefers coastal areas, although it displays an offshore distribution linked to its association with the Gulf of Florida.

In the most recent interpretations of oceanic biogeography, the tropical gyre of the South Atlantic is a distinct province in terms of biogeochemistry that displays unique physical and biological characteristics in relation to the adjacent areas. However, the oligotrophic ocean waters of the South Atlantic are among the least studied of the Atlantic Ocean (LONGHURST, 1998), which is evident from the scarcity of samples in the region and the few studies related to the planktonic community (BOLTOVSKOY, 1995). PIONTKOVSKY et al. (2003) analyzed samples from expeditions conducted between 1963 and 1999 and confirmed the patterns of zooplankton biomass on a macroscale in the anticyclonic gyre of the South Atlantic with the majority of the data between 10 ${ }^{\circ} \mathrm{S}$ and $10^{\circ} \mathrm{N}$. FINENKO et al. (2003) also analyzed 30 years of data from expeditions in the region and found seasonal variations in the biomass patterns of the tropical and subtropical Atlantic, although limited data were found on the central gyre of the South Atlantic.

The "Transatlantic Commission I" was undertaken between Brazil and Africa aboard the oceanographic research vessel Cruzeiro do Sul in 2009 and encompassed a particular region of the South Atlantic. This subtropical portion of the South Atlantic is notable for the important oceanographic features such as the Brazil Current (BC) and Malvinas Current (MC), Subtropical Convergence, recirculation of the South Atlantic Central Water (SACW), and the systems of the Benguela and Agulhas Currents. From a morphological perspective, this region possesses important features of the Mid-Atlantic Ridge. The interaction of these physical and geological processes are important modulators of the biology of the oceanic regions and contribute to the hypotheses of changes in biodiversity and biogeography of planktonic organisms. This study is linked to the Zooplankton of the South Atlantic (ZSA) project, which seeks to contribute to the data on biodiversity, distribution and biogeography of diverse taxonomic groups of zooplankton in the oceanic regions of the South Atlantic. It is the first analysis that has specifically focused on the spatial distribution of the genus Lucifer in this subtropical portion of the South Atlantic. This study seeks to clarify and provide increased data on the distribution of prawns of the family Luciferidae in the subtropical South Atlantic because additional studies are required to determine the patterns of composition, abundance and spatial distribution of this group in the study area. If we add the entire intricate network of the environmental interrelations to the topographical variations in the study area and if we further link it to the life strategies of these crustaceans, we can provide an insight into the complexity to evaluate the distribution of these organisms and the need for a considerable effort, from the scientific and technological points of view, for a better understanding at the specific level.

\section{MATERIAL AND METHODS}

During the "Transatlantic Commission I", samples of zooplankton were collected from 83 oceanographic stations on two latitudinal profiles extending between Brazil and Africa between October and December of 2009. A total of 42 trawls were made on $30^{\circ} \mathrm{S}$ and 41 trawls on $20^{\circ} \mathrm{S}$ (Figure 1).

At each station, an oblique trawl was performed from the surface to a depth of $150 \mathrm{~m}$, the net having a mesh aperture of $140 \mu \mathrm{m}$ and a diameter of $60 \mathrm{~cm}$ at the opening. A mechanical flowmeter was attached to the net to estimate the volume of water filtered by the trawl. The material collected was immediately transferred to plastic jars and preserved in $4 \%$ buffered formaldehyde. Continuous vertical hydrographic profiles (temperature and salinity) were performed at each sampling station using a CTD (Falmouth Scientific, Inc.; Cataumet, MA, USA) with an attached fluorimeter to measure the chlorophyll-a concentration throughout the water column to define the maximum chlorophyll-a concentration $\left(\mathrm{MCC}, \mathrm{mg} \cdot \mathrm{m}^{-3}\right.$ ) depth. 


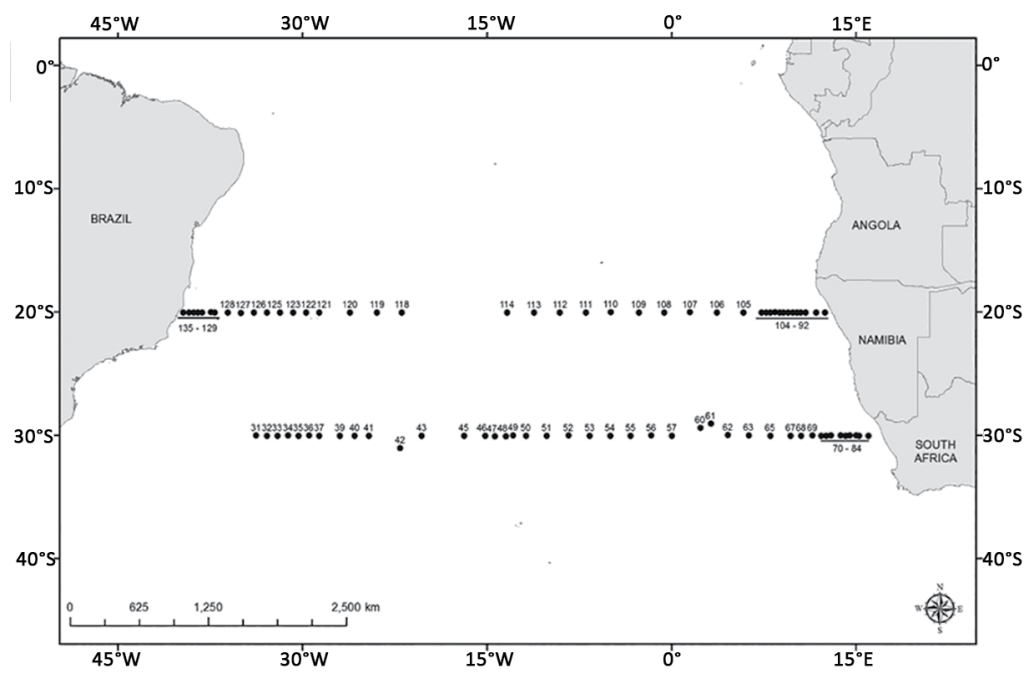

Figure 1. The "Transatlantic Commission I". Oceanographic stations in two latitudinal profiles $\left(20^{\circ}\right.$ and $\left.30^{\circ} \mathrm{S}\right)$ between Brazil and Africa. Samples collected between October and December 2009.

The zooplankton samples, with sorted and counted shrimp of the Luciferidae family, were examined in a Bogorov chamber under a Nikon SMZ800 dissecting microscope. The sex and developmental stage were also determined.

Identification of the Lucifer species was performed in accordance with BOWMAN and MCCAIN (1967), BOLTOVSKOY (1981) and D'INCAO (1997). The organisms were counted, and their densities estimated according to the number of organisms per $100 \mathrm{~m}^{3}$ of water. The data for underwater currents were assessed based on STRAMMA and ENGLAND (1999) and SILVEIRA et al. (2000).

The data transformation considered that the distribution of the abundance of different taxa is asymmetrical and direct. Thus, the data for the abundance were transformed to the power of four to control for the assumption of the statistical analyses (HAIR JÚNIOR et al., 1995).

Student's t-test was used to verify the spatial variation between the sampled latitudes using the total abundance of the Luciferidae shrimp and the abiotic variables, such as temperature $\left({ }^{\circ} \mathrm{C}\right)$, salinity and maximum chlorophyll-a concentration $\left(\mathrm{mg} \cdot \mathrm{m}^{-3}\right)$, on the $20^{\circ}$ and $30^{\circ} \mathrm{S}$ parallels. To verify the spatial variation in the distribution of the Lucifer genus and the environmental variables in relation to the Mid-Atlantic Ridge, 32 sampling stations west of 15 ${ }^{\circ} \mathrm{W}$ longitude towards the Brazilian continental shelf and 51 stations east of $15^{\circ} \mathrm{W}$ longitude towards the African continental shelf were evaluated. The geographical position of the ridge was based on CARDOSO et al.
(2013). The possible relations among the abiotic variables of temperature, salinity and maximum chlorophyll- $a$ concentration and the total abundance of the Luciferidae shrimp were verified using multiple linear regression analysis. The valid regression models were checked by applying an ANOVA (overall goodness of fit). These analyses were performed with a STATISTICA 7 software package and considering significant differences when $p<0.05$.

The sex ratio was determined by using a Chi-square test $\left(\mathrm{c}^{2}\right)$ performed in the program Bioestat 5.0. The differences were considered significant for the analyses at $p<0.05$.

The map layouts were created using the ArcGIS 10.1 program in TIF format with 24-bit true color at 200 dpi $(1100 \times 850$ pixels $)$. The interpolation of the data was performed using the natural neighbor interpolation method.

\section{RESULTS}

Two species of the genus Lucifer were identified in this study: L. faxoni (360 adults and 40 mysis II) and $L$. typus (710 adults). L. faxoni displayed distinctive sex ratios with the former exhibiting a significantly greater number of females in relation to males 1:0.5 (Chi-squared test, $\mathrm{c}^{2}=21.77, p=0.0001$ ); in addition, close to $10 \%$ of the individuals of this species were in their early phases, which made sexual identification impossible. The sex ratio of $L$. typus was characterized by a significantly greater 


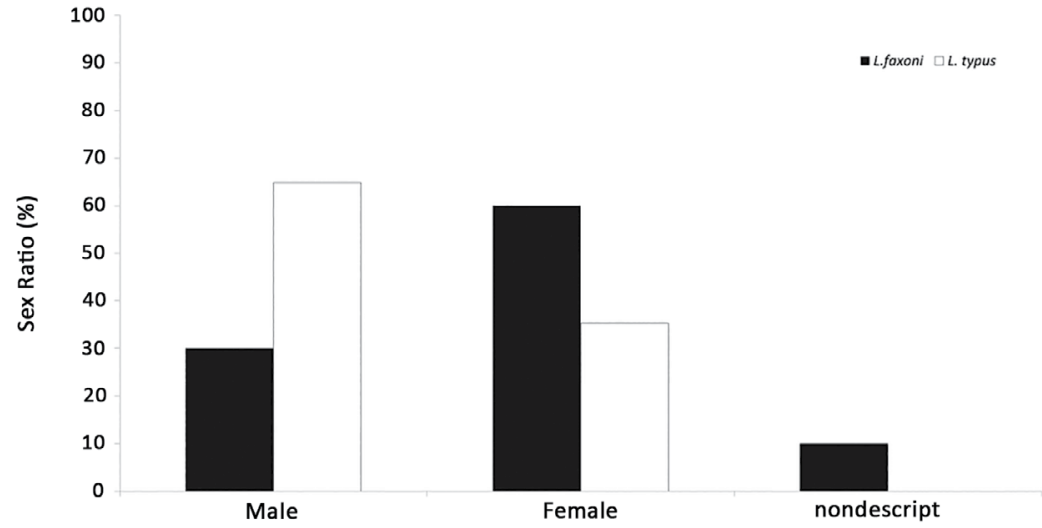

Figure 2. Sex ratio for both species of Lucifer gender, early stages of development of Lucifer faxoni with sex not set appear as nondescript.

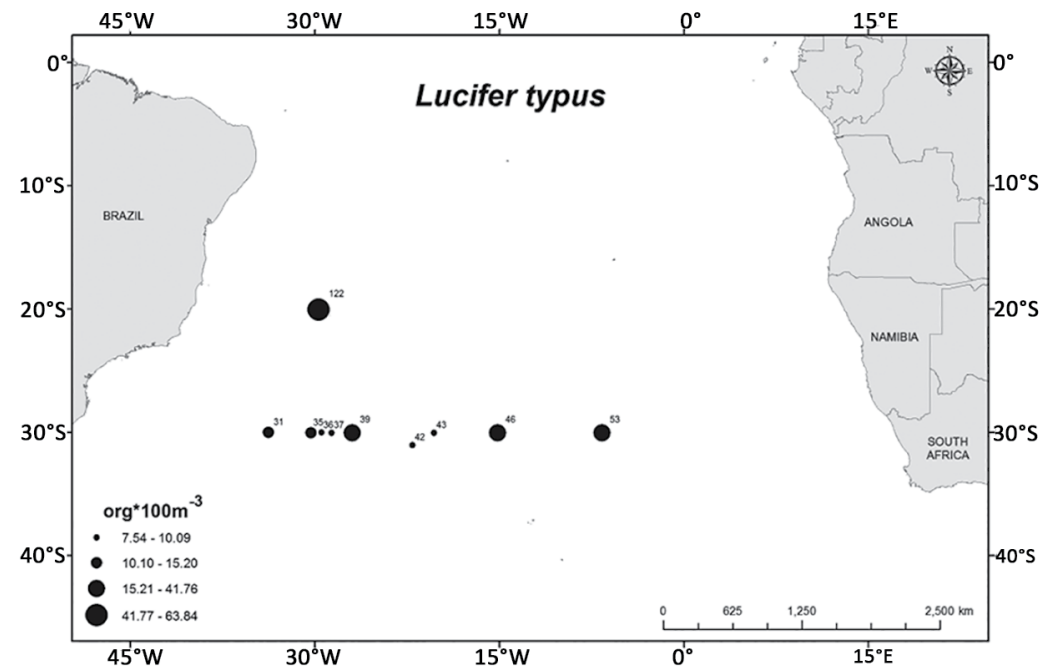

Figure 3. New distribution and abundance of Lucifer typus in the South Atlantic Ocean. In two latitudinal profiles $\left(20^{\circ}\right.$ and $\left.30^{\circ} \mathrm{S}\right)$ between Brazil and Africa. Samples collected between October and December 2009.

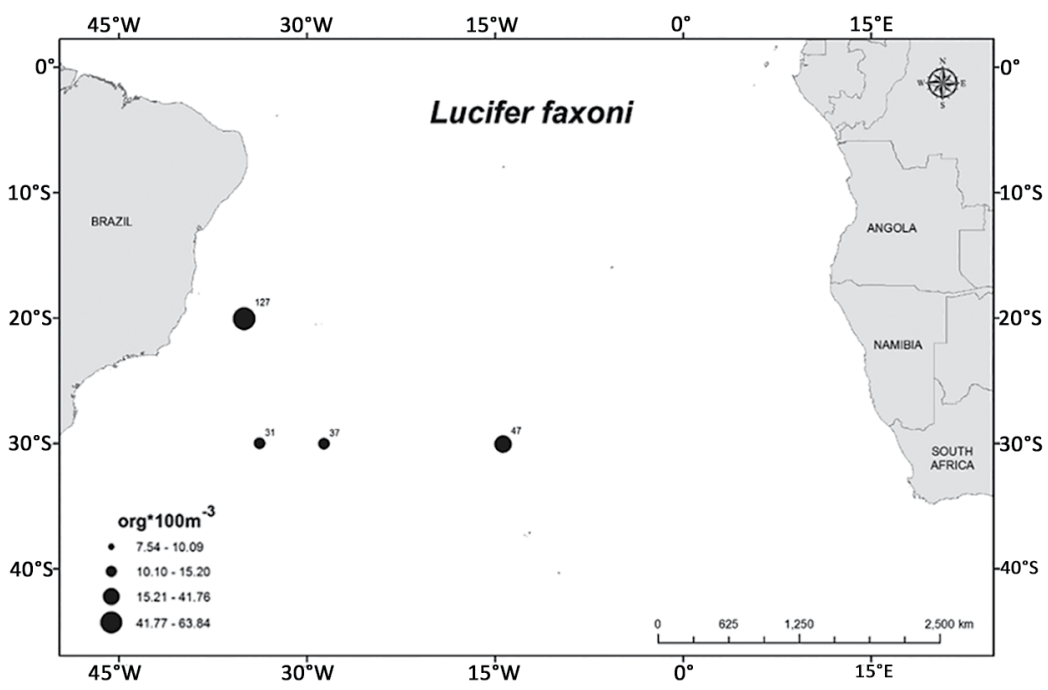

Figure 4. New distribution and abundance of Lucifer faxoni in the South Atlantic Ocean. In two latitudinal profiles $\left(20^{\circ}\right.$ and $\left.30^{\circ} \mathrm{S}\right)$ between Brazil and Africa. Samples collected between October and December 2009. 


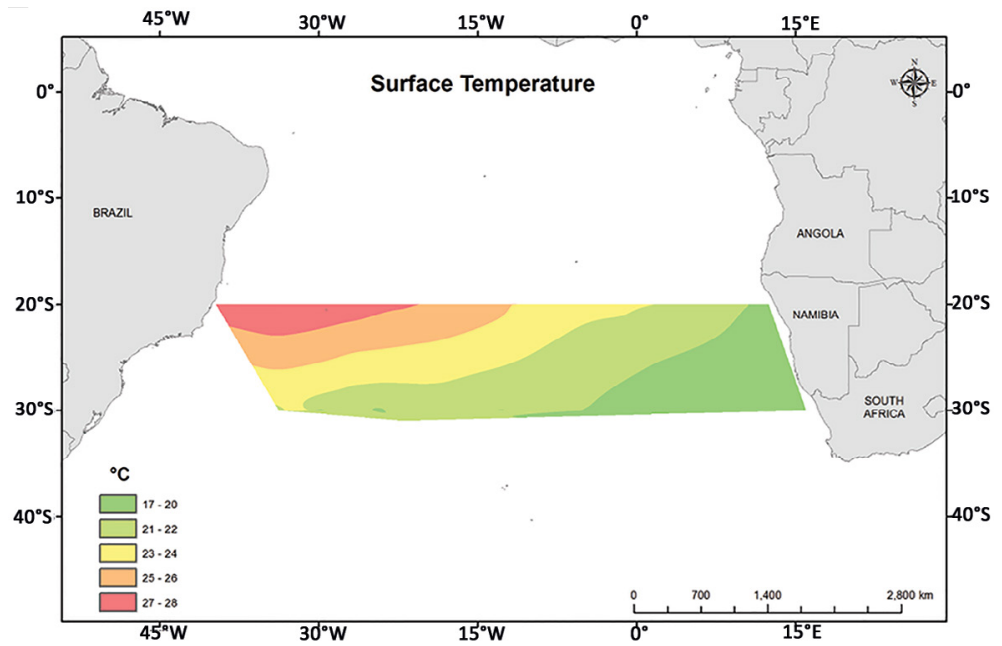

Figure 5. Surface Temperature profile $\left({ }^{\circ} \mathrm{C}\right)$. In two latitudinal profiles $\left(20^{\circ}\right.$ and $\left.30^{\circ} \mathrm{S}\right)$ between Brazil and Africa. Samples collected between October and December 2009.

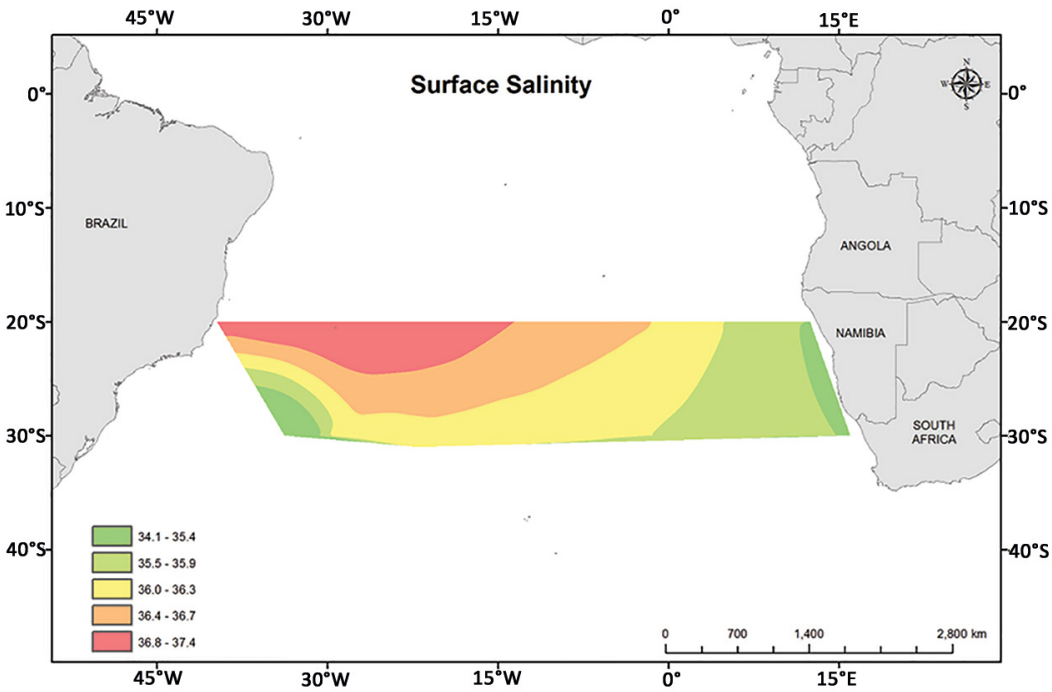

Figure 6. Surface salinity regime. In two latitudinal profiles $\left(20^{\circ}\right.$ and $\left.30^{\circ} \mathrm{S}\right)$ between Brazil and Africa. Samples collected between October and December 2009.

number of males than females at 1.86:1 (Chi-squared test, $\left.\mathrm{c}^{2}=50.84, p=0.0001\right)$ with males representing $64.8 \%$ of the organisms of this species in the study area (Figure 2).

Luciferidae shrimp presented frequencies of occurrence of $2.44 \%$ on the $20^{\circ} \mathrm{S}$ parallel and $23.81 \%$ on the $30^{\circ} \mathrm{S}$ parallel. L. typus was the most frequent species at $30^{\circ} \mathrm{S}$ with $21.43 \%$ occurring at nine sampling stations, whereas $L$. faxoni had a $7.14 \%$ representation occurring only at 3 stations (Figures 3 and 4). Higher abundances of L. typus were observed at $30^{\circ} \mathrm{S}$, and differed significantly between the two latitudes (Student's t-test, $p=0.04$ ). No significant differences were registered for $L$. faxoni abundance between the two parallels (Student's t-test, $p=0.38$ ) and the same pattern was observed as for the Lucifer genus total abundance (Student's $t$-test, $p=0.07$ ).

To check the distribution of the Luciferidae shrimp related to the Mid-Atlantic Ridge, 32 sampling stations to the west of longitude $15^{\circ} \mathrm{W}$ and 51 stations to the east of this meridian toward the African continental shelf were evaluated. In the western portion of the study area, L. typus and L. faxoni showed frequencies of occurrence of $28.13 \%$ and $9.38 \%$, respectively. In the eastern portion of the study area, the two species of these shrimp had a $1.96 \%$ frequency of occurrence. The highest abundances of the Luciferidae shrimp were recorded in the western portion of the Mid-Atlantic Ridge. The total abundances 


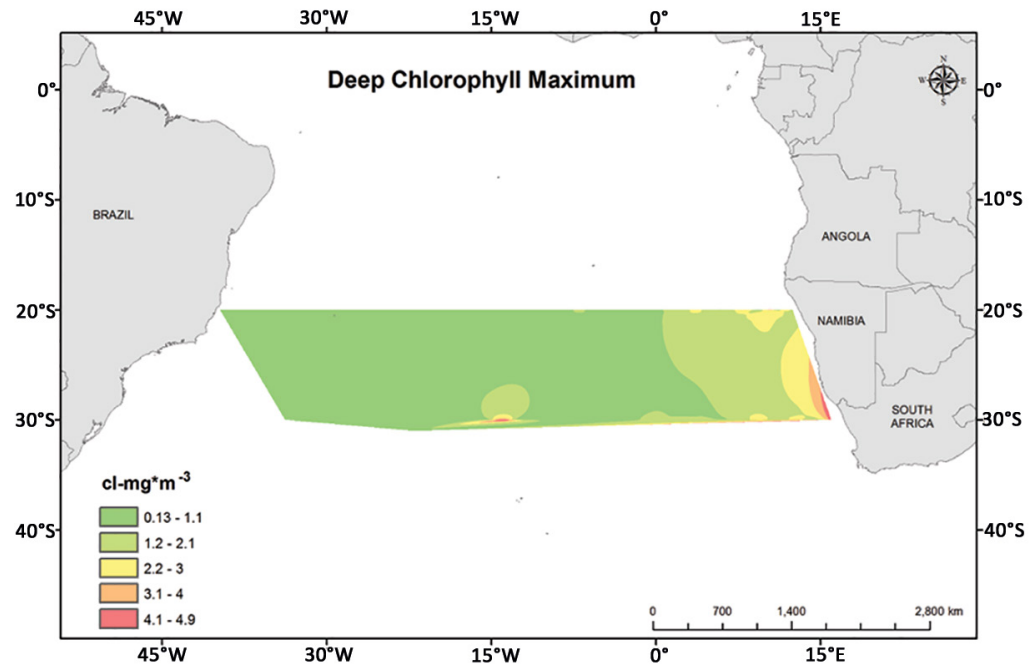

Figure 7. Maximum concentration of chlorophyll-a (MCC, $\left.\mathrm{mg} \mathrm{m}^{-3}\right)$ in the water column. In two latitudinal profiles $\left(20^{\circ}\right.$ and $\left.30^{\circ} \mathrm{S}\right)$ between $\mathrm{Brazil}$ and Africa. Samples collected between October and December 2009.

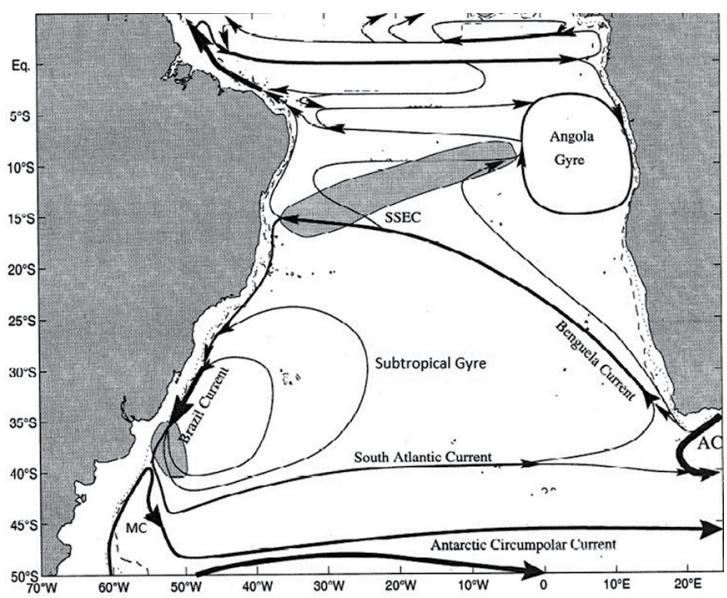

Figure 8. Schematic representation of the surface circulation in the South Atlantic between parallels $20^{\circ}-30^{\circ} \mathrm{S}$. Shown are the Brazil Current; the Malvinas Current (MC); the South Atlantic Current; the South Equatorial Current (SSEC); the Benguela Current and the Agulhas Current (AC). Adapted from Stramma and England (1999).

of L.typus and L. faxoni in the samples to the east of the Mid-Atlantic Ridge were 41.76 and 28.56 ind. $100 \mathrm{~m}^{-3}$, respectively, and to the west, were 102.60 and 186.60 ind. $100 \mathrm{~m}^{-3}$, respectively. Significant variations in the total abundance of the Lucifer genus (Student's $t$-test; $p=$ 0.0004 ) and the abundance of $L$. typus (Student's $t$-test, $p$ $=0.0006$ ) between the western part and the eastern portion of the mid-oceanic ridge were observed. The abundances of $L$. faxoni did not differ significantly between the longitudes analyzed (Student's t-test, $p=0.13$ ).

The highest surface temperature values were recorded at latitude $20^{\circ} \mathrm{S}$ with a significant difference between the parallels analyzed (Student's $t$-test; $p=0.000$ ). Between the longitudes analyzed, the surface temperature differed significantly (Student's $t$-test; $p=0.000$ ) and ranged from 17 ${ }^{\circ} \mathrm{C}$ in the eastern portion of the study area toward the South African continental shelf to $28{ }^{\circ} \mathrm{C}$ in the western portion of the Atlantic Ocean on the $20^{\circ} \mathrm{S}$ parallel toward the Brazilian continental shelf. On both latitudinal profiles $\left(20^{\circ}\right.$ and 30 ${ }^{\circ} \mathrm{S}$ ), from $0^{\circ}$ longitude, a decrease in surface temperature occurs toward the African continental shelf. However, on the $20{ }^{\circ} \mathrm{S}$ parallel in the Brazilian continental shelf region, the surface temperature is the highest in the study area (Figure 5).

The lowest surface salinity values were recorded in the western portion of the South Atlantic on the parallel 30 ${ }^{\circ} \mathrm{S}$ (34.10). The $20^{\circ} \mathrm{S}$ parallel showed the highest salinity values ranging from 34.88 on the Namibian continental to 37.41 in the western portion of the study area towards the Brazilian continental shelf. No significant variations were recorded for salinity between parallels $20^{\circ}$ and 30 ${ }^{\circ} \mathrm{S}$ (Student's $t$-test; $p=0.08$ ) or between the eastern and western portions of the study area (Student's $t$-test; $p=$ 0.40) (Figure 6).

Significant differences were recorded for the maximum concentrations of total chlorophyll (MCC) between the eastern and western portions of the study area (Student's $t$-test, $p=0.00$ ). The MCC were recorded at up to a 150 meter depth ranging from $0.123 \mathrm{mg} \cdot \mathrm{m}^{-3}$ to the west of the Mid-Atlantic Ridge to $4.98 \mathrm{mg} \cdot \mathrm{m}^{-3}$ on the African continental shelf. In some areas $\left(30^{\circ} \mathrm{S}\right.$ and $20^{\circ} \mathrm{S}$ ), the MCC reached depths greater than 125 meters, but the MCC tended to decrease with depth towards the 
South African continental shelf. From $0^{\circ}$ towards the coast of Namibia, the MCC was above a 50 meter depth (rising over the continental shelf), which is extended due to the beginning of the Walvis Ridge. Over this region, it is possible to identify a core with high concentrations of total chlorophyll $>3 \mathrm{mg} \cdot \mathrm{m}^{-3}$ as far as the coast of Namibia, which is characterized as being a high primary productivity region. However, at $20^{\circ} \mathrm{S}$ latitude, the $\mathrm{MCC}$ is observed from the formation of the Vitoria-Trindade Chain as far as the continental shelf break in Brazil in the Abrolhos Bank region, which is below 50 meters in depth with concentrations ranging from 0.123 to $1 \mathrm{mg} \cdot \mathrm{m}^{-3}$. This characterizes this region as oligotrophic because of the low concentration of total chlorophyll-a. There were no significant variations between the MCC on either of the parallels analyzed (Student's $t$-test, $p=0.15$ ) (Figure 7).

A significant relationship was only observed between L. typus abundance and salinity $\left(\mathrm{R}^{2}=0.13\right.$; ANOVA (overall goodness of fit); $\mathrm{F}=4.0 ; p=0.009$ ). This relationship occurred due to a higher abundance of these crustaceans in the western portion of the studied area where higher salinity values were recorded for the subtropical South Atlantic.

\section{DISCUSSION}

FUGIMURA et al. (2005) indicates that L. typus is a shrimp that prefers oceanic conditions, whereas L. faxoni prefers coastal conditions. In this study, both species were recorded in the Subtropical Gyre of the South Atlantic, although they had previously been recorded in open ocean waters in the BC front and South Atlantic Current (SAC); however, only L. faxoni was identified in the BC proper. The results indicate that these species are associated with the BC and SAC oceanic currents and are transported in the tropical gyre of the South Atlantic with a dynamic similar to that found in the North Atlantic by BOWMAN and MCCAIN (1967), where these same species are dispersed by the Florida Current toward oceanic regions.

The distinct sex ratios verified for both species of the genus Lucifer in this study support the data of LÓPEZ (1966), who found a relation between males and females similar to that of L. faxoni in the region of Cananéia. However, in studies by ALVAREZ (1988) along the coast of Santos, and FUGIMURA et al. (2005) in the bay of Sepetiba, RJ, a higher frequency of males was observed in relation to females, although their measurements were similar to those found in this study for L. typus.
The differences observed between L. faxoni and L. typus could be associated with the reproductive strategies of each species (LEE et al., 1992). ALVAREZ (1988) found that the sex ratio in L. faxoni is variable throughout the year, and despite exhibiting continuous reproduction, the reproductive peak of this species occurred in July throughout the Santos coastal region, Brazil $\left(24^{\circ} 16^{\prime \prime} \mathrm{S}\right.$, $\left.46^{\circ} 00 \mathrm{~W}\right)$. The low abundance of the initial stages of this species may be related to the reproductive cycle of these organisms in the region. The absence of nauplii in the samples was also cited by ALVAREZ (1988) and may be related to the inefficiency of capturing this phase of development for the genus Lucifer. Females of the genus Lucifer migrate vertically at night to avoid predation, search for food resources or protect their eggs. The aggregation of females could occur at depths and in the regions with more suitable food resources and may be a method of avoiding predation; these reasons may explain disparity in the sex ratio observed in this study (LEE et al., 1992).

With respect to the bodies of water in the study area, which are described in the bibliography of SILVEIRA et al. (2000), the SACW is found flowing in the region of the pycnocline at temperatures greater than $6{ }^{\circ} \mathrm{C}$ and lower than $20^{\circ} \mathrm{C}$ and salinity between 34.6 and 36. More precisely, MIRANDA (1985) suggests that $20{ }^{\circ} \mathrm{C}$ and 36.20 represents the thermohaline index of this body of water. EMÍLSON (1961) indicates that tropical water (TW) is part of the warm and saline body of water that occupies the surface of the tropical South Atlantic and is transported south by the BC. SILVEIRA et al. (2000) characterize the TW as having temperatures greater than $20{ }^{\circ} \mathrm{C}$ and salinity greater than 36 . The lowest surface temperature and salinity values were registered to the east of the Mid-Atlantic Ridge, which indicates upwelling from deeper waters in the region and the predominance of the TW in the epipelagic layer of the western portion of the area studied. Among the biotic and abiotic factors, a significant relationship was observed only between $L$. faxoni abundance and salinity. This relationship occurred due to the higher abundance of these crustaceans in the western portion of the study area where the highest salinity values were registered. Previous studies indicate that these shrimp present preferences for regions with higher salinity, which act as a barrier to their spatial distribution (TEODORO et al., 2012; ALVAREZ, 1988). The observed spatial variation was characterized by the greater abundances of these crustaceans in the western 
portion of the study area, indicating that the genus Lucifer in the South Atlantic occurs preferentially in oligotrophic areas where the epipelagic region is dominated by the TW.

The contour current that encloses the subtropical gyre of the South Atlantic on its western border is the $\mathrm{BC}$. This current originates at $10{ }^{\circ} \mathrm{S}$ in a region where the southernmost branch of the South Equatorial Current (SEC) bifurcates to form the North Brazil Current (NBC) (Figure 8). The BC then flows south, skirting the South American continent as far as the region of the Subtropical Convergence (33-38 $\left.{ }^{\circ} \mathrm{S}\right)$, where it flows together with the MC and diverges from the coast (STRAMMA; ENGLAND, 1999; SILVEIRA et al., 2000). L. faxoni was observed north of the region that contains the $\mathrm{BC}$ and $\mathrm{BC}$ front, indicating that this species may be transported by this current. XU (2010) states that L. typus is a eurythermal and stenohaline species that occurs in tropical oceans. Thus, this species is considered oceanic and occurs at depths greater than 200 m (BOWMAN; MCCAIN, 1967). In this study, L. typus exhibited greater distribution in the sample area than did L. faxoni. This finding supports the literature on the occurrence of this species in oceanic regions with low variations in salinity. In contrast, L. faxoni is described in the literature as a species with a preference for coastlines, although records indicate that it has been found in regions of greater depth (BOWMAN; MCCAIN, 1967; D'INCAO, 1997). The results of this study indicate that L. typus may be transported in the South Atlantic Subtropical Gyre by the BC and SAC. The results also indicate that L. faxoni, despite having a preference for the coast, is transported to oceanic regions by the $\mathrm{BC}$, and both species are limited in distribution to the subtropical gyre of the South Atlantic. The occurrence of these species covers an area where the SACW is formed by the sinking of waters in the confluence zones of the $\mathrm{BC}$ and the MC. This water is then transported in the direction of Africa by the SAC (STRAMMA; ENGLAND, 1999). These currents can limit the dispersion of these species in the subtropical gyre of the South Atlantic.

Despite the close relationship between abiotic factors and species abundance, the Lucifer genus was restricted to the subtropical gyre of the South Atlantic. The pattern described for surface temperature in the two latitudinal profiles $\left(20^{\circ} \mathrm{S}\right.$ and $\left.30^{\circ} \mathrm{S}\right)$ was similar to that observed for salinity in the study area. The intrusion of colder and less saline waters on the African continental shelf may be observed along with warmer and more saline waters in the subtropical gyre of the South Atlantic in the western portion of the study area. This was a determinant for a significant relationship between salinity and $L$. faxoni abundance, as this species was more abundant and frequent in this portion of the South Atlantic.

In general, shrimp of the family Luciferidae were more frequent and abundant at sampling stations west of the MidAtlantic Ridge. L. typus was the most representative species, both in abundance and distribution, which determined its greater weight in the analysis of species variance. L. faxoni was observed in the $\mathrm{BC}$ and SAC. This study presents the first record of this species in the South Atlantic Subtropical Gyre.

\section{ACKNOWLEDGEMENTS}

The authors would like to thank the Conselho Nacional de Desenvolvimento Científico e Tecnológico (CNPq) for the research support grant, the ZAS group (UFES/ FURG/UFPR) for their participation on the expeditions, Alessandro, Tatiana, Bárbara and Miodeli for their excellent fieldwork, and the crew of the Noc Cruzeiro do Sul for their support at sea.

\section{REFERENCES}

ALVAREZ, M. P. J. Estudo do desenvolvimento de Lucifer faxoni Borradaile, 1915 (Crustacea, Decapoda, Sergestidae) através das medidas do somito pré-bucal. Rev. Bras. Zool., v. 5, n. 3. p. 371-379, 1988 .

BOLTOVSKOY, D. Atlas dei zooplancton del Atlántico Sudoccidental y métodos de trabajo con el zooplancton marino. Mar del Plata: INIDEP, 1981. 936 p.

BOLTOVSKOY, D. Pelagic biogeography: background, gaps and trends. In: PIERROT-BULTS, A. C.; VAN DER SPOEL, S. (Eds.). Pelagic Biogeography IcoPB II. Proceedings of the Second International Conference. Noordwijkerhout: UNESCO, 1995. p. 53-64.

BOWMAN, T. E.; MCCAIN, J. C. Distribution of the planktonic shrimp, Lucifer, in the Western North Atlantic. Bull. Mar. Sci., V. 17 , n. 3 , p. $660-671,1967$.

CARDOSO, I. On some rare Oplophoridae (Caridea, Decapoda) from the South Mid-Atlantic Ridge. Lat. Am. J. Aquat. Res., v. 41, n. 2, p. 209-216, 2013.

COSTA, R. C.; FRANSOZO, A.; MANTELATTO, F. L. M.; CASTRO, R. H. Occurrence of shrimp species (Crustacea: Decapoda: Natantia: Penaeidea and Caridea), in Ubatuba Bay, Ubatuba, SP, Brazil. Proc. Biol. Soc. Wash., v. 113, n. 3, p. 776-781, 2000.

D’INCAO, F. Espécies do gênero Lucifer Thompson, 1829 no litoral brasileiro (Decapoda: Luciferidae). Nauplius, v. 5, n. 2, p. 139-145, 1997.

EMÍLSSON, I. The shelf and coastal waters off southem Brazil. Bol. Inst. Oceanogr., v. 17, n. 2, p. 101-112, 1961. 
FINENKO, Z. Z.; PIONTKOVSKI, S. A.; WILLIAMS, R.; MISHONOV, A. V. Variability of phytoplankton and mesozooplankton biomass in the subtropical and tropical Atlantic Ocean. Mar. Ecol. Prog. Ser., v. 250, p. 125-144, 2003.

FUGIMURA, M. M. S.; OSHIRO, L. M. Y.; SILVA, R. Distribuição e abundância das famílias Luciferidae e Sergestidae (Crustacea, Decapoda, Natantia) na baía de Sepetiba, Rio de Janeiro, Brasil. Rev. Univ. Rural, v. 25, n. 2, p. 52-59, 2005.

HAIR JÚNIOR, J. F.; ANDERSON, R. E.; TATHAM, R. L.; BLACK, W. C. Multivariate data analysis with readings. 4th ed. New Jersey: Prentice Hall, 1995. 745 p.

LEE, W. Y.; OMORI, M.; PECK, R. W. Growth, reproduction and feeding behavior of the planktonic shrimp, Lucifer faxoni Borradaile, off the Texas Coast. J. Plankton Res., v. 14, n. 1, p. 61-69, 1992.

LONGHURST, A. Ecological geography of the sea. London: Academic Press, 1998. 398 p.

LÓPEZ, M. T. Biología de Lucifer faxoni, Borradaile 1915, en Cananéia, Brasil (crustácea, decapoda, luciferidae). Bol. Inst. Oceanogr., v. 15, n. 1, p. 47-54, 1966.

MIRANDA, L. B. Forma da correlação T-S de massas de água das regiões costeira e oceânica entre o Cabo de São Tomé (RJ) e a Ilha de São Sebastião (SP), Brasil. Bol. Inst. Oceanogr., v. 33, n. 2, p. 105-119, 1985.
PIONTKOVSKI, S. A.; LANDRY, M. R.; FINENKO, Z. Z.; KOVALEV A. V.; WILLIAMS, R.; GALLIENNE, C. P.; MISHONOV, A. V.; SKRYABIN, V. A.; TOKAREV, Y. N.; NIKOLSKY, V. N. Plankton communities of the South Atlantic anticyclonic gyre. Oceanol. Acta, v. 26, n. 3, p. 255-268, 2003.

SILVEIRA, I. C. A.; SCHMIDT, A. C. K.; CAMPOS, C. E. J. D.; GODOI, S. S.; IKEDA, Y. A Corrente do Brasil ao Largo da Costa Leste Brasileira. Rev. Bras. Oceanogr., v. 48, n. 2, p. 171-183, 2000.

STRAMMA, L.; ENGLAND, M. On the water masses and mean circulation of the South Atlantic Ocean. J. Geophys Res., v. 104, p. 20863-20883, 1999.

TEODORO, S. S. A.; NEGREIROS-FRANSOZO, M. L.; SIMÕES, S. M.; LOPES, M.; COSTA, R. C. Population ecology of the planktonic shrimp Lucifer faxoni Borradaile, 1915 (Crustacea, Sergestoidea, Luciferidae) of the southeastern coast of Brazil. Braz. J. Oceanogr., v. 60, n. 2, p. 245-253, 2012.

VEGA-PÉREZ, L. A.; ARA, K.; LIANG, T. H.; PEDREIRA, M. M. Feeding of the planktonic shrimp Lucifer faroni Borradaile, 1915 (Crustacea: Decapoda) in the laboratory. Rev. Bras. Oceanogr., v. 44, n. 1, p. 1-8, 1996.

XU, Z. L. Determining optimal temperature and salinity of Lucifer (Dendrobranchiata: Sergestoidea: Luciferidae) based on field data from the East China Sea. Plankton Benthos Res., v. 5 , n. 4 , p. $136-143,2010$. 
